\title{
GAMBARAN TINDAKAN PENCABUTAN GIGI TETAP DI PUSKESMAS TINUMBALA KECAMATAN AERTEMBAGA KOTA BITUNG TAHUN 2013
}

\author{
${ }^{1}$ Masagus Hardadi \\ ${ }^{2}$ Jimmy Maryono \\ ${ }^{3}$ Ni Wayan Mariati
}

\author{
${ }^{1}$ Kandidat Skripsi Program Studi Pendidikan Dokter Gigi Fakultas Kedokteran Universitas \\ Sam Ratulangi Manado \\ ${ }^{2}$ Fakultas Kedokteran Universitas Sam Ratulangi Manado \\ ${ }^{3}$ Program Studi Pendidikan Dokter Gigi Fakultas Kedokteran \\ Universitas Sam Ratulangi Manado \\ E-mail: hardadididit@yahoo.co.id
}

\begin{abstract}
Teeth play some significant role in mastication. The lower efficiency of mastication is mostly caused by tooth loss. Tooth extraction is closely linked to problems such as caries, periodontal, diseases, and other dental diseases. This was a retrospective study. Samples were obtained by using total sampling method. Data of the medical records of tooth extraction in dental health center at Clinic Tinumbala Aertembaga District of Bitung in 2013 were used in this study. The results showed that tooth extraction cases with radix gangrene and periodontal diseases had the same frequencies (41.2\%). Based on gender, males (51.9\%) had a higher frequency of tooth extraction than females. Adults (2665 years) belonged to the highest group with tooth extraction (70.3\%). Type of teeth that mostly extracted is 46 by $17.7 \%$.
\end{abstract}

Keywords: tooth extraction

\begin{abstract}
Abstrak: Gigi merupakan organ terpenting pada manusia. Terjadinya kehilangan gigi akan menyebabkan penurunan efisiensi pengunyahan. Pencabutan gigi berhubungan erat dengan masalah karies, penyakit periodontal, dan penyakit-penyakit lainnya. Penelitian ini bersifat retrospektif dan pengambilan sampel dilakukan dengan metode total sampling dengan cara mendata rekam medik tindakan pencabutan gigi di poli gigi Puskesmas Tinumbala Kecamatan Aertembaga Kota Bitung pada tahun 2013. Hasil penelitian menunjukkan kasus pencabutan gigi dengan diagnosis gangren radiks dan penyakit periodontal mempunyai frekuensi yang sama yaitu sebesar 41,2\%. Berdasarkan jenis kelamin laki-laki (51,9\%) memiliki frekuensi pencabutan gigi yang lebih tinggi dibandingkan perempuan. Kelompok usia dewasa penuh (26-65 tahun) menunjukkan frekuensi pencabutan gigi yang paling tinggi dibandingkan kelompok usia lainnya, yakni sebesar 70,3\%. Jenis gigi yang paling banyak dicabut ialah gigi 46 sebesar 17,7\%.
\end{abstract}

Kata kunci: pencabutan gigi

Gigi merupakan organ terpenting pada manusia. Gigi berfungsi sebagai pengunyah setiap makanan yang masuk ke mulut untuk diteruskan ke dalam tubuh manusia. Proses ini berlangsung mulai dari masa kanak-kanak sampai dewasa. Kehilangan gigi akan menyebabkan penurunan efisiensi pengunyahan yang berhubungan erat dengan masalah karies, penyakit periodontal, dan penyakitpenyakit lainnya. Sistem pengunyahan dianggap suatu masalah multikompleks baik dokter gigi maupun pasien. Indonesia merupakan negara berkembang, sebagian masyarakatnya memiliki tingkat ekonomi menengah ke bawah. Kondisi ekonomi seperti ini, umumnya akan menyebabkan kesadaran masyarakat terhadap kesehatan termasuk kesehatan gigi dan mulut, menjadi berkurang. Hasil Riset Kesehatan Dasar (RISKESDAS) 2007 yang dilakukan oleh Departemen 
Kesehatan menyebutkan prevalensi karies gigi atau gigi berlubang di Indonesia adalah $75 \%$, dan prevalensi pencabutan gigi sebesar 79,6\%, dan Sulawesi Utara termasuk dalam provinsi dengan prevalensi tertinggi masalah kesehatan gigi dan mulut yaitu sebesar $86,6 \%{ }^{1}$

Berbagai upaya pelayanan kesehatan gigi dan mulut telah dilakukan namun prevalensi penyakit gigi dan mulut terus meningkat. Salah satu penyakit gigi dan mulut yang banyak dikeluhkan yaitu gigi berlubang. Gigi berlubang ini tidak bisa dibiarkan karena dapat mempengaruhi kesehatan tubuh secara umum dan secara lebih lanjut berdampak pada pengeluaran biaya pengobatan yang tinggi. ${ }^{2}$

Kesadaran masyarakat tentang arti pentingnya kunjungan ke dokter gigi masih saja kurang. Dengan kata lain, kesadaran akan pencegahan pada sakit gigi masih kurang terutama bagi masyarakat menengah kebawah. Umumnya kebiasaan memeriksakan gigi tersebut jarang dilakukan karena alasan ekonomi atau alasan lain, sehingga penyakit pulpa dan periodontal sudah berada dalam kondisi lanjut. Kondisi ini pada umumnya masih bisa diobati, tetapi perawatan yang ada harus melewati beberapa tahapan dengan waktu yang relatif lama dan biaya yang tinggi, sehingga pencabutan gigi seringkali menjadi pilihan utama.

Masyarakat hanya berpikir untuk segera mencabut gigi jika gigi mereka bermasalah. Persepsi dalam proses pencabutan gigi di masyarakat yang paling ditakutkan ialah munculnya rasa nyeri. Akan tetapi, harus diketahui bahwa rasa nyeri pada saat pencabutan gigi dapat dikendalikan ketika dokter gigi melakukan prosedur anastesi dengan baik dan benar. ${ }^{3}$ Beberapa penelitian telah dilakukan untuk mengetahui alasan pencabutan gigi pada masyarakat salah satunya penelitian mengenai alasan pencabutan gigi pada masyarakat dilakukan oleh Mansur Al Qudah, Haider Al Waeli dan Hatem Al Rashdan pada bulan juni tahun 2004 menemukan bahwa karies menjadi alasan pencabutan gigi paling banyak pada masyarakat di Jordania, yaitu dengan persentase $34,8 \%$ sedangkan penyakit periodontal menduduki peringkat kedua dengan hasil persentase 30,6\%. ${ }^{4}$ Penelitian lain dilakukan oleh Renata dkk pada tahun 2003 menemukan alasan pencabutan gigi pada masyarakat di kota Maceio Brazil pada usia 18-76 tahun, karies juga menjadi alasan pencabutan gigi yang paling banyak, dengan hasil persentase $63,3 \%$ dan penyakit periodontal juga menjadi alasan kedua yaitu $13,1 \%{ }^{5}$

Di Indonesia telah dilakukan penelitian oleh Wita Puspitasari tentang alasan pasien untuk pencabutan gigi pada bulan JuliAgustus tahun 2007 ditemukan alasan pasien untuk pencabutan gigi karies menjadi alasan yang paling banyak dengan hasil presentase $37 \%$ dan gigi impaksi menjadi alasan kedua yaitu dengan persentase $33 \%{ }^{6}$

Puskesmas Tinumbala Bitung merupakan Puskesmas yang berada di kecamatan Aertembaga, dan merupakan salah satu sarana kesehatan pemerintah. Masyarakat Bitung yang tinggal di Kecamatan Aertembaga memanfaatkan Puskesmas Tinumbala untuk berobat dan mendapatkan pelayanan medis yang murah.

Berdasarkan hasil survei awal, peneliti melihat banyaknya tindakan pencautan gigi, dan belum pernah diadakan penelitian sebelumnya, dengan Melihat banyaknya penelitian tentang pencabutan gigi diikuti dengan prevalensi yang berbeda-beda dan pencabutan gigi merupakan salah satu bentuk pelayanan yang sering dilakukan di Bagian Poli Gigi, sehingga gambaran mengenai pencabutan gigi diperlukan untuk mengetahui tingkat prevalensi masalah kesehatan gigi dan mulut di Sulawesi Utara, oleh sebab itu Puskesmas Tinumbala Bitung menjadi pilihan sebagai tempat untuk melakukan penelitian. Penelitian ini dilakukan dalam kurun waktu satu tahun terakhir.

Tujuan penelitian ini ialah untuk mengetahui gambaran pencabutan gigi di Puskesmas Tinumbala Kecamatan Aertembaga Kota Bitung tahun 2013 dengan tujuan khusus untuk mengetahui gambaran pencabutan gigi berdasarkan diagnosis, jenis kelamin, usia dan jenis gigi.

\section{BAHAN DAN METODE}

Penelitian ini merupakan penelitian retrospektif yaitu dengan melihat kembali data dari kartu rekam medik pasien yang sudah dilakukan tindakan pencabutan gigi.

Penelitian dilakukan dengan terlebih dahulu memasukan surat permohonan izin di bagian tata usaha Puskesmas Tinumbala Bitung, setelah mendapat izin dari kepala Puskesmas Tinumbala Bitung, surat izin 
tersebut diteruskan ke Poli Gigi Puskesmas Tinumbala Bitung dan bagian registrasi untuk dilakukan penelitian. Pengambilan data dilakukan dengan melihat data kartu status pasien yang melakukan pencabutan gigi di Puskesmas Tinumbala Kecamatan Aertembaga Kota Bitung selama tahun 2013.

Data yang di dapat kemudian diolah secara manual dan disajikan berdasarkan distribusi frekuensi dalam bentuk diagram batang (histogram).

\section{HASIL PENELITIAN}

\section{Karakteristik Subjek}

Penelitian ini dilakukan dengan cara mengumpulkan data sekunder yang diambil dari bagian registrasi Puskesmas Tinumbala Bitung melalui kartu status pasien. Dari datadata yang diperoleh di bagian rekam medik, ditemukan 100 kartu status pasien dengan tindakan pencabutan gigi tahun 2013, namun berdasarkan kriteria inklusi dan eksklusi yaitu pasien yang melakukan pencabutan gigi permanen dari umur $\geq 13$ tahun dan data dari kartu status pasien yang tidak lengkap jumlah kartu status yang diteliti berjumlah 32 kartu status. Hasil penelitian ini dibagi berdasarkan diagnosis, jenis kelamin, umur, dan jenis gigi yang dicabut.

\section{Distribusi pencabutan gigi berdasarkan diagnosis}

Dari total 32 kartu status dengan jumlah kasus sebanyak 39 tindakan pencabutan gigi dapat dikelompokan penyebab dari pencabutan itu sendiri. (Gambar 3).

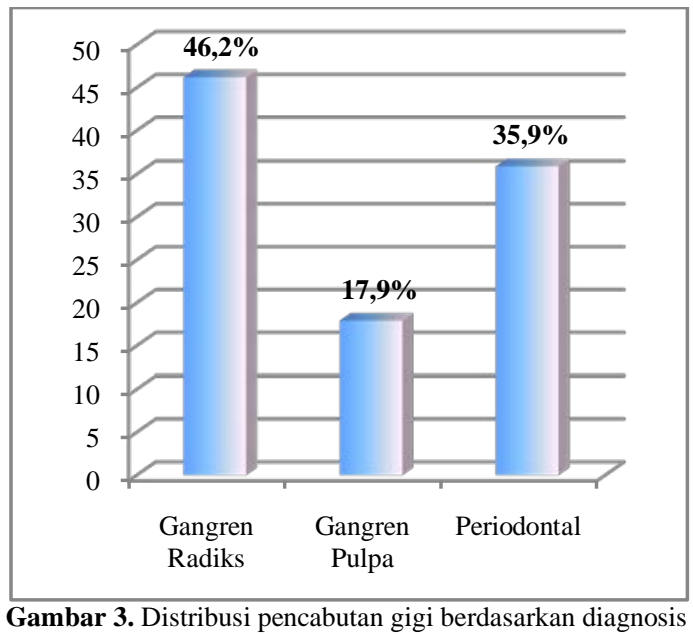

Paling banyak penyebab pencabutan ialah gangren radiks dengan jumlah pencabutan gigi yaitu 18 gigi (46,2\%), pada urutan ke dua ialah penyakit periodontal dengan jumlah pencabutan gigi yaitu 14 gigi (35,9\%), sedangkan gangren pulpa menempati urutan ketiga dengan jumlah pencabutan sebanyak 7 gigi (17,9\%).

\section{Distribusi pencabutan gigi berdasarkan jenis kelamin}

Berdasarkan kartu status di bagian poli gigi Puskesmas Tinumbala Bitung tahun 2013 laki-laki lebih sering dilakukan pencabutan gigi. (Gambar 4).

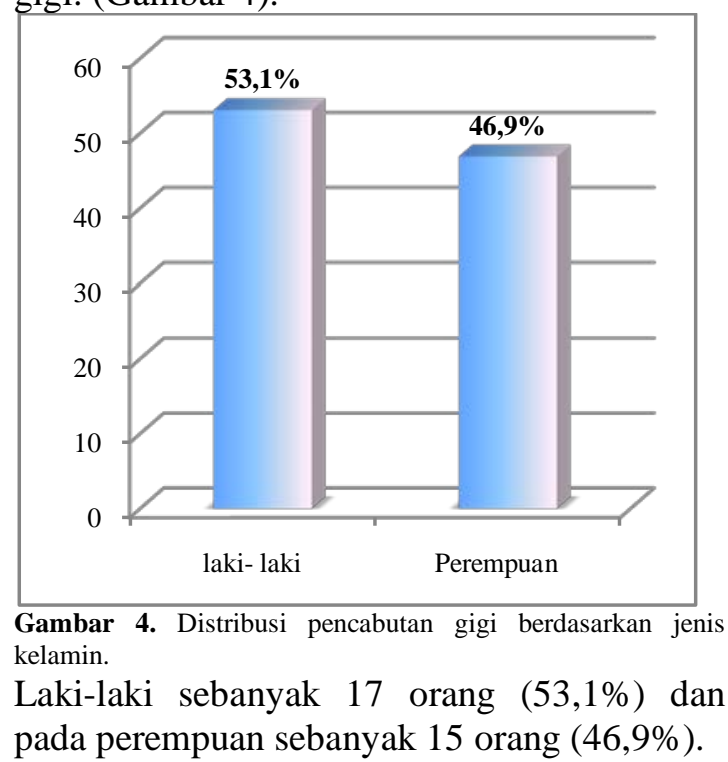

\section{Distribusi pencabutan gigi berdasarkan usia}

Dari 32 kartu status dengan tindakan pencabutan gigi sebanyak 39 kasus yang dilakukan di Puskesmas Tinumbala Kota Bitung, berdasarkan umur jumlah tertinggi ialah kategori usia 65 tahun ke atas (Gambar $5)$.

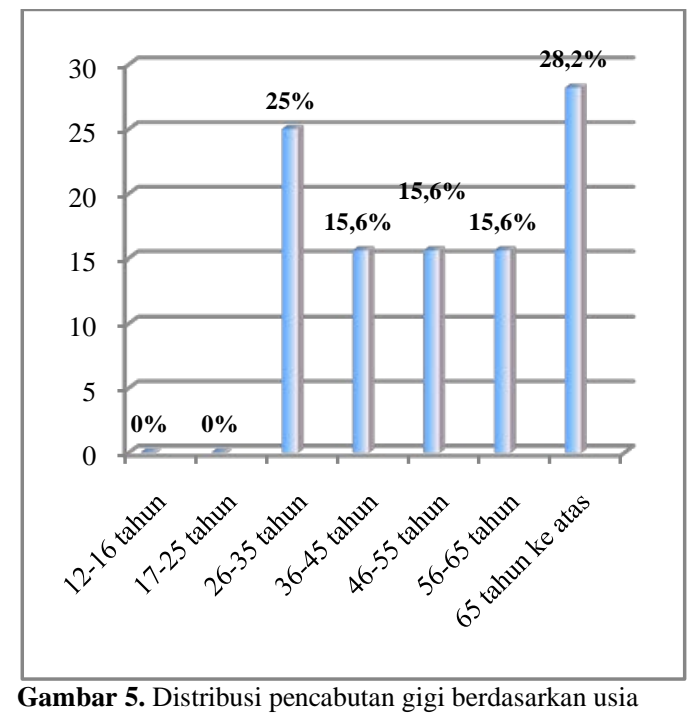


Usia 65 tahun ke atas sebanyak 9 orang (28,2\%), kategori usia 26-35 tahun sebanyak 8 orang (25\%), pada kategori usia 36-45 tahun, 46-55 tahun, dan 56-65 tahun dengan jumlah yang sama yaitu 5 orang $(15,6 \%)$, dan pada kategori usia 12-16 tahun dan 17-25 tahun tidak ada kasus pencabutan gigi.

\section{Distribusi pencabutan gigi berdasarkan jenis gigi}

Dari 32 kartu status yang didapat dengan jumlah 39 kasus pencabutan gigi di Puskesmas Tinumbala Kota Bitung, jenis gigi yang paling banyak dicabut yaitu gigi molar I rahang bawah (gigi 46) (Gambar 6). sebanyak 14 gigi (35,8\%), kemudian gigi molar II rahang bawah sebanyak 4 gigi (10,2\%), peringkat ketiga jenis gigi insisivus I rahang atas dan kaninus rahang bawah sebanyak 3 gigi (7,7\%), gigi insisivus I rahang bawah, premolar I rahang bawah, premolar II rahang bawah, dan molar III rahang bawah masingmasing berjumlah 2 gigi $(5,1 \%)$, dan yang terendah jenis gigi insisivus II rahang atas, kaninus rahang atas, premolar I rahang atas, premolar II rahang atas, molar I rahang atas, molar III rahang atas, dan insisivus II rahang bawah berjumlah 1 gigi (2,6\%).

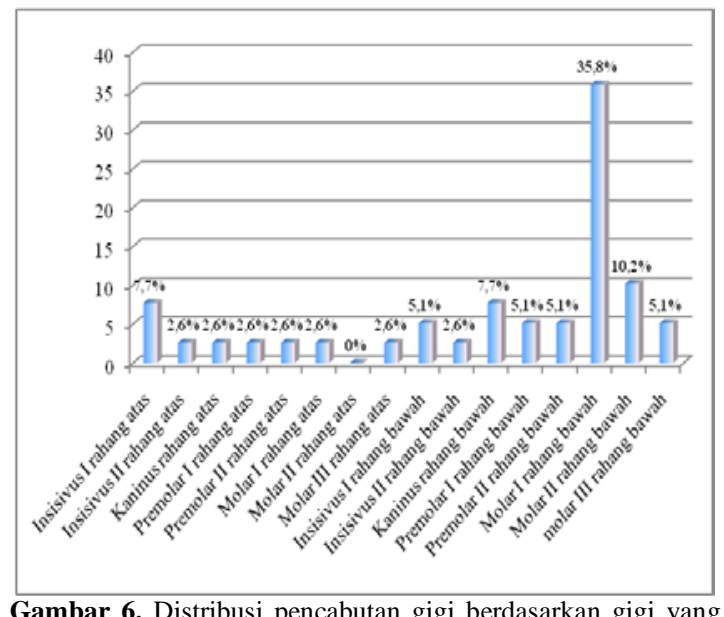
Gamba

\section{BAHASAN}

Berdasarkan hasil penelitian didapatkan bahwa gangren radiks dan periodontal merupakan penyebab atau indikasi paling sering dilakukannya pencabutan gigi di Puskesmas Tinumbala Kecamatan Aertembaga Kota Bitung Tahun 2013. Dari 32 kartu status pasien dengan kasus pencabutan gigi sebanyak 39 kasus ini dikarenakan satu kartu status dengan kasus pencabutan lebih dari satu gigi, 18 kasus atau $46,2 \%$ penyebab pencabutan gigi adalah gangren radiks. Hasil ini sedikit berbeda dengan hasil penelitian Rilly yang meneliti tentang pencabutan gigi di Balai Pengobatan Rumah Sakit Gigi dan Mulut (BP-RSGM) Fakultas Kedokteran Program Studi Pendidikan Dokter Gigi Universitas Sam Ratulangi. Rilly mendapatkan bahwa pencabutan tertinggi sebanyak 787 (56,65\%) kasus pencabutan gigi dengan diagnosis nekrosis pulpa, diikuti oleh periodontitis sebanyak 163 (12,93\%) kasus. ${ }^{7}$ Namun, persentase banyaknya kasus gangren pulpa berbeda dengan penelitian yang dilakukan di Puskesmas Bitung Barat Kecamatan Maesa Kota Bitung Tahun 2012 oleh Wulan bahwa persentase penyebab pencabutan gigi paling banyak adalah penyakit periodontal sebesar 489 (91,7\%) kasus. $^{8}$ penelitian lain juga dilakukan di beberapa negara seperti penelitian yang dilakukan di Jordania bahwa karies menjadi penyebab pencabutan gigi yang paling banyak, jumlah 184 kasus dengan hasil persentase $34,8 \%{ }^{4}$

Perbedaan hasil yang didapatkan peneliti bisa disebabkan oleh beberapa faktor. Faktor pertama ialah perbedaan tempat penelitian seperti yang diungkapkan oleh Al-Sharafat bahwa perbedaan budaya mempengaruhi hasil penelitian juga dengan jumlah sampel yang berbeda mempengaruhi hasil persentase. Faktor lainnya bisa diasumsikan disebabkan pasien menunda atau tidak ingin untuk melakukan perawatan, mereka lebih memilih minum obat untuk menghilangkan rasa sakit sehingga proses karies itu terus berlanjut menjadi gangren radiks. ${ }^{9}$

Gangren radiks adalah suatu keadaan dimana gigi sudah tinggal akarnya atau mahkota gigi sudah hilang sampai batas garis servikal. Proses terjadinya gangren radiks diawali oleh proses karies, dengan adanya karies yang mengenai email (karies superfisial) selanjutnya proses berlanjut menjadi karies pada dentin (karies media). Hal ini disebabkan karena sisa akar yang tidak dicabut bisa membuat tidak nyaman pada pasien.

Penyakit periodontal dengan jumlah sebanyak 14 (35,9\%) kasus, proses terjadinya penyakit periodontal berawal dari penumpukan plak pada gigi yang terdeposit kemudian berlanjut sampai terjadi penyakit 
periodontal. Faktor ekonomi menjadi alasan penyebab pencabutan yang satu ini mengingat bahwa perawatan untuk periodontitis lumayan mahal, ini dikarenakan sarana dan prasarana di puskesmas yang kurang memadai sehingga perawatan untuk penyakit periodontal tidak bisa dilakukan.

Distribusi pencabutan gigi berdasarkan jenis kelamin menunjukan pada pasien lakilaki berjumlah 17 orang atau 53,1\% dan perempuan berjumlah 15 orang atau $46,9 \%$. Hasil penelitian ini tidak jauh berbeda dengan hasil penelitian yang dilakukan oleh Dariush tentang alasan pencabutan gigi di Iran tahun 2010 yaitu berdasarkan jenis kelamin laki-laki lebih sering dilakukan pencabutan gigi dengan 197 kasus atau sebanyak 56,9\% dibandingkan dengan perempuan 142 (43,1\%) kasus. ${ }^{10}$ Pada penelitian yang dilakukan oleh $\mathrm{Al}$ - Sharafat di Jordan dengan hasil penelitian yang berbeda, perempuan lebih sering melakukan pencabutan gigi sebanyak 260 (41,6\%) kasus daripada laki-laki sebanyak 40 orang $(0,77 \%){ }^{9}$ Hasil serupa juga didapatkan oleh Stjepan di Kroasia, yaitu perempuan sebanyak $28,37 \%$ dan laki - laki sebanyak 22,44\%. ${ }^{11}$ Perbedaan hasil yang didapatkan peneliti bisa disebabkan oleh beberapa faktor. Faktor pertama adalah perbedaan tempat penelitian dengan perbedaan budaya mempengaruhi hasil penelitian. Faktor lainnya bisa diasumsikan disebabkan kebiasaan masyarakat kelurahan Tinumbala mengkonsumsi minuman keras dan merokok juga kurangnya pengetahuan tentang kesehatan gigi dan mulut, sehingga menyebabkan kebersihan gigi dan mulut sebagian besar masyarakat laki-laki tergolong kurang baik sedangkan sebagian besar masyarakat perempuan tingkat pengetahuan dan kesadaran tentang kebersihan gigi dan mulut sudah tergolong baik.

Distribusi pencabutan gigi berdasarkan usia menunjukan bahwa kategori usia 65 tahun ke atas yakni sebanyak 9 orang $(28,2 \%)$. Hasil ini tidak jauh berbeda dengan yang dilaporkan Dixit dkk tahun 2010 di Nepal bahwa usia >30 tahun 189 pasien $(79,1 \%)$ memiliki frekuensi pencabutan gigi lebih tinggi. ${ }^{12}$ Aida dkk melaporkan hasil penelitian dari 9115 pencabutan gigi yang dilakukan di Jepang 2342 orang atau 25,7\% adalah pasien dengan umur $55-64$ tahun. ${ }^{13}$ Hal ini bisa terjadi oleh beberapa faktor yaitu karena keadaan jaringan periodontal dari pasien itu sendiri semakin tua umur seseorang maka jaringan periodontal semakin menurun, keinginan untuk membuat gigi palsu, atau keadaan sistemik dari pasien yang mengharuskan pasien untuk mencabut giginya contohnya penderita diabetes mellitus. Penelitian yang dilakukan oleh Thomas di Ajman University of Science and Technology (AUST) melaporkan bahwa pasien dengan umur 50 tahun keatas kebanyakan melakukan pencabutan gigi karena periodontitis. Faktor lainnya ialah mereka merasa lebih nyaman dan percaya bila melakukan pencabutan gigi di Rumah Sakit. ${ }^{14}$

Distribusi pencabutan gigi berdasarkan jenis gigi menunjukan bahwa jenis gigi permanen yang paling banyak dicabut ialah gigi molar pertama rahang bawah 14 kasus atau $35,8 \%$. Hasil ini serupa dengan yang dilaporkan Ryan Irwanto Tunggal dalam penelitiannya di Rumah Sakit Tingkat III TNI AD Robert Wolter Monginsidi Manado tahun 2012 bahwa gigi molar pertama rahang bawah memiliki frekuensi pencabutan gigi yang paling tinggi 20,86\% dan yang paling rendah adalah gigi kaninus rahang bawah 1,19\%.32 Sharafat dkk tahun 2008 di Jordan juga melaporkan bahwa molar pertama rahang bawah memiliki frekuensi yang paling tinggi $15,53 \%$ sebanyak 160 gigi dan gigi kaninus rahang bawah memiliki frekuensi pencabutan yang paling rendah $3,11 \%$ sebanyak 32 gigi. $^{15}$

Gigi molar pertama merupakan gigi permanen pertama yang erupsi di rongga mulut sekitar umur 6 tahun. Gigi ini mempunyai peranan penting dalam proses mastikasi dan juga menjadi patokan untuk keharmonisan sebuah oklusi.

Menurut Itjiningsih, gigi molar pertama rahang bawah rawan untuk mengalami kerusakan karena merupakan gigi permanen yang pertama erupsi di dalam rongga mulut. ${ }^{16}$ Selain itu, gigi molar merupakan gigi yang memiliki pit dan fisur pada permukaan oklusal sehingga memudahkan plak terselip jika tidak dibersihkan dengan baik. Plak ini mengandung bakteri yang merupakan tahap awal terbentuknya karies atau penyakit periodontal. ${ }^{17}$ Gigi kaninus rahang bawah memiliki frekuensi pencabutan yang paling rendah disebabkan karena gigi kaninus merupakan gigi yang paling panjang di dalam mulut. ${ }^{16}$ Gigi kaninus juga merupakan gigi anterior sehingga kesehatan gigi anterior 
biasanya lebih mendapat perhatian sebagai faktor estetik seseorang.

\section{SIMPULAN}

1. Pencabutan gigi di Puskesmas Tinumbala Kecamatan Aertembaga Kota Bitung tahun 2013 menunjukan tindakan pencabutan paling banyak dilakukan dengan diagnosis gangren radiks sebanyak 18 gigi (46,2\%).

2. Distribusi pencabutan gigi berdasarkan jenis kelamin paling banyak ditemukan pada laki-laki yaitu sebanyak 17 orang $(53,1 \%)$

3. Distribusi pencabutan gigi berdasarkan umur ditemukan jumlah tertinggi ialah kategori usia 65 tahun ke atas yakni sebanyak 9 orang $(28,2 \%)$,

4. Distribusi pencabutan gigi berdasarkan jenis gigi ialah gigi molar I rahang bawah sebanyak 14 gigi $(35,8 \%)$.

\section{SARAN}

Bagi pihak puskesmas agar dapat meningkatkan pelayanan kesehatan gigi dan mulut sehingga masyarakat lebih tertarik untuk terus melakukan chek up kesehatan gigi dan mulut di Puskesmas Tinumbala Kecamatan Matuari Kota Bitung, dapat memperhatikan sarana dan prasarana puskesmas dan pengisian kartu status oleh petugas kesehatan haruslah lengkap dan tepat sesuai dengan pemeriksaan yang telah dilakukan.

\section{DAFTAR PUSTAKA}

1. Anonimous. Sambutan Menteri kesehatan republik Indonesia pada peringatan bulan kesehatan gigi nasional 2011. [online]. 2012 Mei 03 [cited 2013 juni 28]; Available from:URL:http://www.pdgi.or.id/artikel/ detail/sambutan-menteri-kesehatanrepublik-indonesia-pada-peringatanbulan-kesehatan-gigi-nasional-2012.

2. Napitupulu LE. Anak-anak dan Orang Dewasa Hadapi Masalah Gigi Berlubang. KOMPAS.com. [online]. 2012 Oct 01 [cited 2013 Mar 12]; Available from:URL:http://edukasi.kompas.com/re ad/2012/10/01/19193310/anakanak.dan.orang.dewasa.hadapi.masalah.g igi.
3. Purwanto P.T. Rasa Nyeri saat Pencabutan Gigi. JOGLOSEMAR. [online]. 2012 oct 13 [cited 2013 Mar 12]; Available

from:URL:http://edisicetak.joglosemar.c o/berita/rasa-nyeri-saat-pencabutan-gigi101598.html.

4. Qudah M.A, Waeli H.A. The reasons for dental extraction of permanent teeth in Jordanian population, including considerations for the influence of social factors. Smile Dental Journal. 2012; (7)1. P.34.

5. Jovino R.C, Caldas A.F, Souzab E.H.A, Gusmaoc E.S. primary reason for tooth extraction in a Brazilian adult population. Original Article. 2005;3:3. P.151.

6. Puspitasari Wita. Alasan Pasien untuk Pencabutan Gigi. Fakultas Kedokteran Gigi Universitas Padjadjaran. SKRIPSI; Bandung.2008. P. 5,25-6,30.

7. Ngangi R. Gambaran pencabutan gigi di balai pengobatan rumah sakit gigi dan mulut Universitas Sam Ratulangi tahun 2012. Journal e-GIGI 2013; (1)2.

8. Panelewen A. W. Gambaran pencabutan gigi permanen di Puskesmas Bitung Barat Kecamatan Maesa Kota Bitung tahun 2012. Journal e-GIGI 2013; (1)2.

9. Sharafat FSA, Negrish ARSA. Reasons for Extraction of Teeth in Central Region of Jordan. Pakistan Oral \& Dental Journal 2008; (28)2. P. 234.

10. Dariush Amanat, Sara Pourshahidi, Hooman Ebrahimi, Shahrokh Gheisari and Neda Amanat. Reasons for teeth extraction in southern regions of Iran, in 2010 short title:teeth extraction in Iran. Elixir International Journal 2010.

11. Spalj S, Plancak D, Juric H, Pavelic B, and Bosnjak A. Reason For Extraction Of Permanent Teeth In Urban And Rural Population Of Croatia. Coll. Antropol. 2004; 28.

12. Dixit LP, Gurung CK, Gurung N, Joshi N. Reasons Underlying the Extraction of Permanent Teeth in Patients Attending Peoples Dental College and Hospital. Nepal Medical College Journal. 2010; 12(4).

13. Aida $\mathrm{J}$ et al. Reasons for Permanent Tooth Extractions in Japan. Journal of Epidemiology 2006; (16)5.

14. Thomas S. Causes And Pattern Of Tooth Mortality Among Adult Patients In A 
Teaching Dental Hospital. Ibnosina Journal Of Medicine And Biomedical Sciences. 2010; (4)2: P. 160-167.

15. Tunggal, RI. Distribusi Frekuensi Tindakan Ekstraksi Gigi di Rumah Sakit Tingkat III TNI AD Robert Wolter Mongisidi Manado. Manado: Program Studi Kedokteran Gigi Fakultas
Kedokteran Universitas Sam Ratulangi. 2012. H. 23-5.

16. Itjingningsih WH. Anatomi Gigi. Jakarta: EGC; 2012. hal. 213-14, 17.

17. Kidd A. M. Edwina. Dasar-dasar Karies. Penyakit dan Penanggulangannya. Buku Kedokteran EGC: Jakarta 1991. hal. 4. 